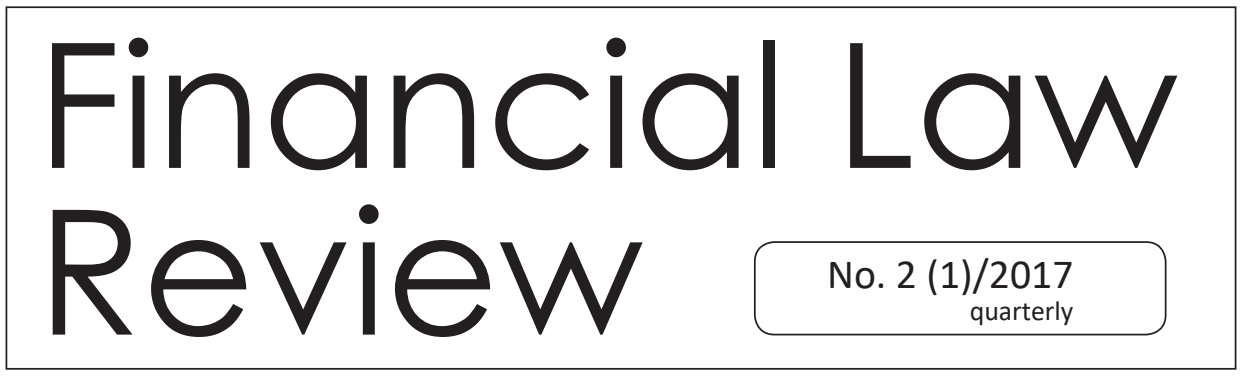

UNIVERSITY OF GDAŃSK • FACULTY OF LAW AND ADMINISTRATION

http://www.ejournals.eu • http://czasopisma.bg.ug.edu.pl

\title{
ALTERNATIVE DISPUTE RESOLUTION MECHANISM IN THE AREA OF FINANCIAL SERVICES IN EUROPEAN UNION ${ }^{1}$
}

Damian Cyman

\section{Summary}

The development of a single European market in retail financial services has resulted in a growing awareness within the European Union of the importance of efficient alternative dispute resolution mechanisms for consumers. The purpose of this document is to analyze existing Alternative Dispute Resolution Mechanisms in the area of financial service in European Union, including European and Polish regulations. Author described characteristic of Alternative Dispute Resolution (ADR), initiatives taken by European Union aiming to ensure the right level of consumer protection and both existing and proposed regulations. The article adresses the issue of ADR bodies in the Member States and Financial Services Complaints Network (FIN-NET). Research carried out in the article made it possible to present proposals in conclusions.

\footnotetext{
${ }^{1}$ The article is a reprint of the article originally published in System prawnofinansowy: prawo finansowe wobec wyzwań XXI wieku. Law and finance: the financial law towards challenges of the XXI century / J. Gliniecka (red.), CeDeWu, Warszawa 2013
} 


\section{Introduction}

The financial services available in Europe are constantly evolving. The integration of financial services markets gave European consumers a greater choice of financial services, facilitated by the increasing purchase of financial services through internet ${ }^{2}$. Financial institutions provides usually a wide spectrum of financial services, using new technologies ${ }^{3}$. However, in order to have confidence in buying financial services from providers established in other Member States, consumers need to have easy access to justice in case of dispute. The development of a single European market in retail financial services has resulted in a growing awareness within the European Union of the importance of efficient alternative dispute resolution mechanisms for consumers. The consumers' trust in the Single Market is affected by the lack of confidence that their problems related to purchases of financial services can be addressed efficiently. ADR schemes fulfill right for access to justice, which is a fundamental right enshrined in Article 6 of the European Convention for the Protection of Human Rights and Fundamental Freedoms. The right to valid remedies has been determined by the European Court of Justice to be general principle of Community law ${ }^{4}$ and proclaimed as such by Article 47 of the Charter of Fundamental Rights of the European Union.

\section{Characteristic of Alternative Dispute Resolution (ADR)}

Alternative Dispute Resolution (ADR) schemes are out-of-court mechanisms, that have been developed to help consumers who have been unable to reach an agreement directly with the trader. ADR schemes usually use a third party (arbitrator, mediator, ombudsman, complaint board) to help the consumer and the trader reach a solution: resolve their dispute by proposing or imposing a solution or by bringing the parties together to convince them to find a solution by common agreement. Essentially, consumer dispute resolution procedures cannot be designed to replace court procedures, but to realize a higher level of consumer protection.

Usually, ADR schemes propose much quicker and cheaper way to settle disputes than in state courts. It offers more flexibility than going to court and can

\footnotetext{
${ }^{2}$ Globalization of financial markets is noticeable not only in European Union, but also in the whole earth- see A.M. Jurkowska- Zeidler, "Bezpieczeństwo rynku finansowego w świetle prawa Unii Europejskiej”, Oficyna, Warszawa 2008, p.61 and next.

3 See E.Juchnevic, M. Stvol, „Problematyka prawna transferu środków pieniężnych $w$ świetle nowych technologii", Prawo bankowe No. 9, 2005, p. 49 and next

${ }^{4}$ Case 222/84 Johnston [1986] ECR 1651.
} 
better meet the needs of both consumers and professionals. Therefore, they are appreciated by both consumers and financial services providers. ADR schemes also improve access to justice, as they provide an opportunity to resolve disputes in more comfortable ways. Compared to going to court, these schemes are cheaper, much quicker and more informal which means they are an attractive means for consumers seeking redress. Because of independent third party, the decision are considered as very just and therefore, are often followed by both parties. What is important, ADR schemes increase consumer confidence in financial services, because consumers know they will have wider opportunity to solve their dispute. When consumers cannot resolve their disputes with financial services providers bilaterally, not many of them consider going to court. They give up claims, but their trust in financial institutions and financial system is lowered.

ADR schemes are present on all developed financial markets all over the world. For example, The USA has a long and rich experience of ADR schemes in various forms. They have been able to develop because they were supported by the court system. Especially in the past two decades, ADR has become a major aspect of legal practice in the United States and developed in many different ways (Arbitration, Mediation, Conciliation, Fact-Finding, Mini-trial, Summary Jury Trials, Court-ordered arbitration, Ombudsman, Med- Arb, Small Claims Courts, Rent-a-Judge $)^{5}$. Each has distinctive values and is useful in certain types of disputes. Some of them operate within the current litigation system. They are public tribunals, that have added non-judge-centered means to resolve what is otherwise an ordinary litigation. Others involve privatized form of dispute resolution, that takes parties completely out of state courts.

Important role of ADR has been noticed in European Union as well. EU citizens appear to lack confidence in their ability to win in a dispute with a bank or an insurance company.. For example in Poland, $87 \%$ of consumers believes so, and only $3 \%$ believes, that it is easy (on the contrary, only $56 \%$ of consumers in Luxembourg believes it is difficult to win) $)^{6}$. Empirical data shows that before bringing a case to court, a consumer estimates how much time, money and effort

\footnotetext{
5 K. Stone, „Alternative Dispute Resolution” in Encyclopedia of Legal History, Public Law \& Legal Theory Research Paper Series, Research Paper No. 04-30, University of California, Los Angeles 2001.

${ }^{6}$ Public Opinion in Europe on Financial Services, European Commission Special Eurobarometer, TNS Opinion \& Social, August 2005, p. 71.
} 
will be required to obtain redress and then weighs these considerations against the value of the claim ${ }^{7}$.

There are many ways to implement ADR in the area of financial services. The currently existing ADR schemes either cover financial services in particular sectors ${ }^{8}$, all financial services sectors ${ }^{9}$ or handle consumer complaints in general ${ }^{10}$. They are established by public authorities ${ }^{11}$ or private actors- associations of financial services providers ${ }^{12}$ or associations of financial services providers in cooperation with consumer ${ }^{13}$. ADR schemes in European Union apply different procedures. For example, the decision on how the dispute should be settled may be binding for both the consumer and the financial services provider or binding only on the financial services provider, and consumer can file a claim with the court. Some ADR schemes are restricted only to make a recommendation to the parties, which they are free to follow, or even to help the parties to come to an agreement. It is also very important to ensure the right level of protection of trade secrets, in particular financial secrecy ${ }^{14}$.

\section{Online Dispute Resolution (ODR) as a form of ADR}

Online Dispute Resolution (ODR) may be defined as dispute resolution processes conducted with the assistance of communications and information technology, particularly the internet. Similar terms are "online ADR", “eADR", "iADR", "virtual ADR", "cyber mediation" and "cyber arbitration." It has its origin in settling disputes concerning internet matters, especially related to electronic commerce ${ }^{15}$. It is logical that persons having a conflict related to the internet, try to solve this

\footnotetext{
7 According to Eurobarometer 342, 39\% of European consumers did not go to court after a problem they encountered because the sums involved were too small or the procedure would be too expensive with respect to the sum involved.

8 Banking Ombudsman in Italy, Insurance Ombudsman in Germany, Ombudsman of the Authority of Financial Markets in France.

9 Financial Ombudsman Service in United Kingdom, the Consumer Complaints Manager of the Malta Financial Services Authority, Financial Services Complaints Institute in Dutch.

${ }_{10}$ National Board for Consumer Complaints in Sweden, State Consumer Protection Authority in Lithuania.

${ }^{11}$ Complaints Service of the Bank of Spain, Financial Services Ombudsman's Bureau in Ireland.

12 Ombudsman of the German Cooperative Banks.

13 Complaint Boards in Dutsch.

${ }^{14}$ See J. Gliniecka, „Tajemnica finansowa. Aspekty aksjologiczne, normatywne i funkcjonalne”, Wyd. Oficyna Wydawnicza BRANTA, Bydgoszcz-Gdańsk 2007

15 Lucille M. Ponte, "Boosting Consumer Confidence in E-Bisuness: Recommendations For Establishing Fair and Effective Dispute Resolutions Program for B2C Online Transactions", Albany Law Journal of Science and Technology, No 441, 2001-2002, p. 441 and next.
} 
through the internet as well. Usually consumers engage in small or medium transactions, which they would usually not have done in the traditional market. In these cases, courts are too expensive, mainly because of costs of filing, travel and legal counsel and they are too slow. That is why courts are often an economically unreasonable medium to solve disputes arising out of internet ${ }^{16}$. It is commonly said, that ODR would become more and more popular due to constant increase of e-business transactions ${ }^{17}$. There are no specific reasons to limit ODR to disputes related to e-business, or generally to internet matters. Consumer disputes in an traditional context, when suited for ADR, can equally well be subjected to ODR. For some disputants, online dispute resolution (ODR) makes sense due to the challenges posed by geographic distances, time and scheduling concerns, or the other obstacles posed by face-to-face meetings. There is wide spectrum of communication methods can be used, what makes this way of solving disputes very useful ${ }^{18}$.

\section{European initiatives on ADR}

The European Council has repeatedly stressed the importance it attaches to alternative means of settling disputes, especially in cross-border transactions. At the Lisbon European Council in March 2000 devoted specifically to "Employment and the Information Society", the European Council invited the "Commission and the Council to consider how to promote consumer confidence in electronic commerce, in particular through alternative dispute resolution systems ${ }^{19}$. The Council asked the Commission to prepare a Green Paper taking stock of the current situation and launching broad consultations on the measures to be taken. Commission's Green Paper on alternative dispute resolution in civil

${ }_{16}$ For example SquareTrade is an ADR scheme, that resolve conflicts concerning eBay sales (C2C), though it offers facilitated negotiation or mediation in off line disputes, see also: Susan Summers Raines and Melissa Conley Tyler: "From e-bay to Eternity: Advances in Online Dispute Resolution", Legal Studies Research Paper No. 200 Melbourne Law School, January 2007.

17 David A. Larson, “Online Dispute Resolution: Do You Know Where Your Children Are?" Plenum Publishing Corporation Negotiation Journal July 2003, p. 199, David Allen Larson, “Technology Mediated Dispute Resolution (TMDR): Opportunities and Dangers", University of Toledo Law Reviev, Vol. 38, p. 213.

18 In example email - a virtually instantaneous transfer of mainly text messages; instant messaging - a variant on email that allows synchronous online chat; online chat - a synchronous, text-based exchange of information; threaded discussion (also known as bulletin boards) - an asynchronous, textual exchange of information organized into specific topics; video/audio streams - asynchronous transfer of recorded messages, videoconferencing - synchronous transfer of video information.

19 Paragraph 11 of the Presidency conclusions. 
and commercial law ${ }^{20}$ noticed, that ADR is a political priority, repeatedly declared by the European Union institutions, whose task it is to promote these alternative techniques, to ensure an environment propitious to their development and to do what it can to guarantee quality.

Alternative methods of dispute resolution, for the purposes of the Paper, were defined as out-of-court dispute resolution processes conducted by a neutral third party, excluding arbitration proper. This definition resulted in excluding arbitration schemes leading to binding decisions from the scope of the Paper. In its staff working document on the initiatives in the area of retail financial services, accompanying the Communication "A single market for $21^{\text {st }}$ century Europe", the European Commission announced that its services will examine further the possibilities of improving alternative redress mechanisms in the field of financial services, since gaps in their geographical and sectoral coverage still remain. In its resolution on the Green Paper, the European Parliament requested that consumers have access to ADR mechanisms both at national and cross-border level and called on the Commission to promote best practices on ADR. In 2007, an analysis and evaluation of alternative means of consumer redress other than redress through ordinary judicial proceedings has been prepared by The Study Centre for Consumer Law - Centre for European Economic Law on Katholieke Universiteit Leuven ${ }^{21}$. The study was commissioned by the European Commission.

To seek the views of the stakeholders on how ADR schemes in the area of financial service, providing consumers with individual redress, could be further improved, European Commission raised in 2008 consultation document: Alternative Dispute Resolution in the Area of Financial Services ${ }^{22}$. As it occurred, there was general recognition by stakeholders of the benefits of ADR schemes. Many of responders agreed, that ADR schemes are an effective way to resolve disputes which cannot be resolved by the consumer and the financial services provider bilaterally. In all opinions responders said, that there is a need to look for ways to improve the possibilities for redress through ADR schemes, though there was different

\footnotetext{
${ }^{20}$ Green Paper on alternative dispute resolution in civil and commercial law, Brussels, 19.04.2002 $\operatorname{COM}(2002)$.

${ }^{21}$ An analysis and evaluation of alternative means of consumer redress other than redress through ordinary judicial proceedings. Final Report. The Study Centre for Consumer Law - Centre for European Economic Law, Katholieke Universiteit Leuven, Leuven, January 17, 2007.

${ }^{22}$ Alternative Dispute Resolution in the Area of Financial Services. Consultation Document. European Commision, Brussels, 11.12.2008, MARKT/H3/JS D(2008)
} 
positions how it should be achieved, and at what level- national or European ${ }^{23}$. To continue researches of ADR schemes, Commission issued document: Alternative dispute resolution for consumer disputes in the Single Market ${ }^{24}$. It said, that ADR development is crucial for raising awareness levels and ensuring that consumers and traders make full use of quality ADR entities.

All mentioned above papers and documents was indented to elaborate appropriate regulations of ADR schemes, that would emphase benefits, they bring both for consumers and entities, in particular financial institutions.

\section{European legislation on ADR in financial services}

European legislation regulating ADR evaluated. At the beginning, two Recommendations adopted by the European Commission have established quality criteria and minimum guarantees that each ADR scheme should offer to its users. Recommendation 98/257/EC ${ }^{25}$ on the principles applicable to the bodies responsible for out-of-court settlement of consumer disputes stated, that all bodies with responsibility for the out-of-court settlement of consumer disputes should respect the following principles: independence, transparency, adversarial procedure, effectiveness, legality, liberty and representation. ADR schemes were limited to procedures where a third party proposes or imposes a decision to resolve the dispute (such as arbitration) but does not cover consensual settlement procedures (such as mediation), or where the third party facilitates the resolution of a consumer dispute by bringing the parties together and assisting them in reaching a solution by common consent

Recommendation 2001/310/EC ${ }^{26}$ on the principles for out-of-court bodies involved in the consensual resolution of consumer disputes established common criteria, that these consensual procedures should meet in order to give consumers and business confidence that their disputes will be handled with fairness, rigor and effectiveness criteria. It do not prescribes how such procedures should operate, but identifies a set of principles that such procedures should

\footnotetext{
${ }^{23}$ Summary of the Responsen to the Public Consultations on Alternative Dispute Resolutions in the Area of Financial Services, European Commision, Brussels, 14 September 2009.

${ }^{24}$ Communication From the Commission to The European Parliament, The Council and The European Economic and Social Committee: Alternative dispute resolution for consumer disputes in the Single Market Brussels, 29.11.2011 COM(2011) 791.

${ }_{25}$ Commission Recommendation 98/257/EC on the principles applicable to the bodies responsible for the out-of-court settlement of consumer disputes, OJ 115, 17.4.1998, p. 31.

${ }_{26}$ Commission Recommendation 2001/310/EC on the principles for out-of-court bodies involved in the consensual resolution of consumer disputes, OJ 109, 19.4.2001, p.56.
} 
follow in order to ensure a common minimum standard principles: facilitate the resolution of a consumer dispute by bringing the parties together and assisting them (mediation).

The two Commission Recommendations have had considerable influence in the Member States and play a central role in the functioning of the FIN-Net networks. ADR schemes which can be considered to respect the principles set out in the Recommendations are notified to the European Commission by Member States for inclusion in a central database. However, because the Recommendations were not binding for Member States, there was different spectrum of its implementation. Detailed law regulations in different countries varied. It restrained cross- border commerce, because of the risk connected with disputes.

Considerable efforts have been made in the Community to regulate development of ADR in financial services in Directives, particularly in the information society context. First directive, that referred to ADR in the area of financial services, was Directive 2002/65/EC concerning the distance marketing of consumer financial services $^{27}$. In its article 14 it states, that "Member States shall promote the setting up or development of adequate and effective out-of-court complaints and redress procedures for the settlement of consumer disputes concerning financial services provided at distance. Member States shall, in particular, encourage the bodies responsible for out-of-court settlement of disputes to cooperate in the resolution of cross-border disputes concerning financial services provided at distance." Directive 2002/92/EC on insurance mediation, ${ }^{28}$ in its article 11 states, that "Member States shall encourage the setting-up of appropriate and effective complaints and redress procedures for the out-of-court settlement of disputes between insurance intermediaries and customers, using existing bodies where appropriate. Member States shall encourage these bodies to cooperate in the resolution of cross-border disputes."

Similar regulations provided Directive 2004/39/EC on markets in financial instruments ${ }^{29}$ in its article 53, regulating extra-judicial mechanism for investors'

${ }_{27}$ Directive 2002/65/EC of the European Parliament and the Council of 23 September 2002 concerning the distance marketing of consumer financial services and amending Council Directive 90/619/EEC and Directives 97/7/EC and 98/27/EC, OJ L 271, 9.10.2002, p. 16-24.

${ }^{28}$ Directive 2002/92/EC of the European Parliament and the Council of 9 December 2002 on insurance mediation, OJ L 9, 15.1.2003, p. 3-10.

${ }_{29}$ Directive 2004/39/EC of the European Parliament and the Council of 21 April 2004 on markets in financial instruments amending Council Directives 85/611/EEC and 93/6/EEC and Directive 2000/12/EC of the European Parliament and of the Council and repealing Council Directive 93/22/ EEC, OJ L 145, 30.04.2004, p. 1-44. 
complaints ${ }^{30}$. Directive 2009/138/EC on the taking-up and pursuit of the business of Insurance and Reinsurance ${ }^{31}$ in article 183 obliged the insurance undertaking to inform the policyholder of the arrangements for handling policyholders' complaints of policyholders concerning contracts including, where appropriate, the existence of a complaints body, without prejudice to the policyholder's right of the policyholder to take legal proceedings.

Payment Services Directive 2007/64/EC ${ }^{32}$ aims at establishing a modern and comprehensive set of rules applicable to all payment services in the European Union, including consumer protection ${ }^{33}$. The Directive not only obliged to inform the complainant of the existence of the out-of-court complaint and redress procedures (if they exists), but also to ensure that adequate and effective out-ofcourt complaint and redress procedures for the settlement of disputes between payment service users and their payment service providers are put in place for disputes concerning rights and obligations arising under this Directive. Moreover, the Directive noticed importance of cross-border disputes and stated, that Member States shall make sure that ADR schemes cooperate actively in resolving those disputes. Those regulations are important also for electronic money holders. Directive on electronic money ${ }^{34}$ states, that out-of-court complaint and redress procedures for the settlement of disputes should be at the disposal of electronic money holders. Out-of court dispute resolution was also regulated in Directive 2008/48/EC on credit agreements for consumers ${ }^{35}$ in its article 24 . It underlined

\footnotetext{
30 "Member States shall encourage the setting-up of efficient and effective complaints and redress procedures for the out-of court settlement of consumer disputes concerning the provision of investment and ancillary services provided by investment firms, using existing bodies where appropriate. 2. Member States shall ensure that those bodies are not prevented by legal or regulatory provisions from cooperating effectively in the resolution of cross-border disputes".

31 Directive 2009/138/EC of the European Parliament and the Council of 25 November 2009 on the taking-up and pursuit of the business of Insurance and Reinsurance (Solvency II), OJ L 335, 17.12.2009, p. 1-155.

32 Directive 2007/64/EC of the European Parliament and the Council of 13 November 2007 on payment services in the internal market amending Directives 97/7/EC, 2002/65/EC, 2005/60/EC and 2006/48/EC and repealing Directive 97/5/EC, OJ L 319, 5.12.2007, p.1- 36.

${ }_{33}$ Por. J.Gliniecka, „Zasada przejrzystości świadczenia usług płatniczych jako warunek bezpiecznego korzystania z elektronicznych instrumentów płatniczych na tle Dyrektywy PSD", Prawo Bankowe No 9 2008, p. 54 and next.

${ }^{34}$ Directive 2009/110/EC of the European Parliament and of The Council of 16 September 2009 on the taking up, pursuit and prudential supervision of the business of electronic money institutions amending Directives 2005/60/EC and 2006/48/EC and repealing Directive 2000/46/EC, OJ L 267, 10.10.2009, p. $7-17$

35 Directive 2008/48/EC of the European Parliament and the Council of 23 April 2008 on credit agreements for consumers and repealing Council Directive 87/102/EEC, OJ L 133, 22.5.2008, p. $66-92$.
} 
the importance of cooperation among bodies in different Member States to resolve cross-border disputes concerning credit agreements.

Due to scattered in a few directives regulations concerning alternative dispute resolutions, works began to compile them in one directive ${ }^{36}$. The Directive on consumer ADR is to ensure quality of ADR entities to deal with contractual disputes. The Directive tackles the three main problem areas that have been identified after consultation with interested parties and using studies that have been carried out on behalf of the Commission, as mentioned above. First problem are gaps in the coverage of ADR entities at both sector-specific and geographical level. Second is lack of awareness and insufficient information preventing consumers and businesses from using ADR entities. The last is variable quality of ADR. As it occurred, significant number of ADR entities are not in line with the core principles laid down by the two Commission Recommendations. The Directive is to ensure, that quality out-of-court entities exist to deal with any contractual dispute between a consumer and a business. ADR entities will have to meet certain quality criteria, i.e. be well-qualified impartial, transparent, effective and fair. Businesses would have to inform customers about the ADR entity, which can deal with a potential contractual dispute with them. ADR entities will resolve the disputes within 90 days.

The European Parliament and the EU Council has committed to adopting the package by the end of 2012 as a priority action in the Single Market Act (see IP/11/469), but this term was not complied. The package also completes one of the actions of the Digital Agenda for Europe. After the adoption, EU Member States will have 18 months to implement the ADR Directive.

There was also paid attention to ODR. Due to proposal of Regulation on consumer $\mathrm{ODR}^{37}$, it will set up an EU-wide online platform for handling disputes between consumers and traders, arising from online transactions. The platform will link all the national alternative dispute resolution entities and will operate in all official EU languages. Traders will be required to provide consumers with adequate information on ADR and ODR. It would enable consumers and traders to access directly an online platform which will help to resolve contractual disputes arising from cross-border online transactions through the intervention

\footnotetext{
${ }^{36}$ Proposal for a of the European Parliament and the Council on alternative dispute resolution for consumer disputes and amending Regulation (EC) No 2006/2004 and Directive 2009/22/EC Directive on consumer ADR), Brussels, 29.11.2011, COM(2011) 793 final, 2011/0373 (COD)

37 Regulation of the European Parliament and the Council on online dispute resolution for consumer disputes, Brussels, 29.11.2011, COM(2011) 794 final 2011/0374 (COD)
} 
of an ADR entity complying with the Directive. The proposal requires traders established within the EU that engage in cross-border e-commerce to inform consumers about the ODR platform. This information shall be made easily, directly, prominently and permanently accessible on the traders' websites as well as when the consumer submit a complaint to the trader.

\section{FIN-NET}

FIN-NET (FINancial Services complaints NETwork) is a network of the competent national ADR bodies which are required to comply with Commission Recommendation 98/257/EC. The European Commission launched Fin-NET on 1 February 2001, as an out-of-court complaints network for financial services to help businesses and consumers resolve disputes in the Internal Market rapidly and efficiently by avoiding, where possible, lengthy and expensive legal action. FIN-NET provides consumers who have problems relating to financial services (banks, insurance companies, investment services) with direct access to an ADR facility. It aims at eliminating the difficulties of obtaining out-of-court redress which are a barrier to the development of cross-border services, particularly in the financial sector.

FIN-NET ensures, that consumers can deal with a national scheme, in their own language designed to allow consumers to contact the out-of-court complaint scheme in their home country even when they have a complaint against a foreign financial services. National ADR schemes assist consumers in identifying and contacting the ADR scheme, which is competent to deal with their complaint. It gives the necessary information about the scheme and its complaint procedure, including: contact details, coverage, organization, in which languages the scheme operates, whether there are any charges to be paid by the consumer, whether the decision of the scheme is binding, typical times for handling complaints. When consumers have all the necessary information about the relevant scheme and have decided to file a complaint with it, they can leave the complaint with the FIN-NET member in their home country, which will then transfer it to the relevant scheme in the service provider's country

Provider members are required to abide by a Memorandum of Understanding which outlines mechanisms and conditions according to which members of FIN-NET cooperate and exchange information in handling consumer complaints. They are either cover financial services in particular sectors (e.g. banking and insurance ombudsmen schemes) or handle consumer complaints in general 
(e.g. consumer complaint bodies) Some of them are central, others are regional or even local; some are public, others are private The status of their decisions varies from mere recommendations to decisions that bind the financial services provider and the complainant

Public authorities support action to make FIN-NET a more comprehensive network. The majority of public authorities suggest non-binding measures, such as awareness-raising, informal contacts by the Commission with those ADR schemes that are not members of FIN-NET. Currently FIN-NET has 56 members from 24 European Economic Area countries (the European Union Member States plus Iceland, Liechtenstein and Norway).

\section{Alternative Dispute Regulations in financial services in Poland}

In Poland, the volume of disputes brought before courts is increasing. The proceedings are becoming more lengthy and the costs incurred by such proceedings are increasing ${ }^{38}$. The quantity, complexity and technical obscurity of the polish legislation makes access to justice more difficult. The specific advantages of ADR schemes and the crisis affecting the effectiveness of justice have led to renewed interest in these methods of dispute resolution, which are more consensual than recourse to the courts or arbitration. ADRs are not a new development in polish law, but have in recent years become increasingly common and have been the focus of more and more attention. However, as for now, the whole system of consumer redress has little transparency and coherence. The regulations are dispersed in many provisions of law and subject to rules proclaimed by special bodies. That makes ADR schemes not too popular.

Proceedings before the court of arbitration have been regulated in Articles 695 729 of the Code of Civil Procedure ${ }^{39}$. The discussed proceedings can be applied for the purpose of resolution of disputes regarding all property-related cases, except for the disputes regarding maintenance and relation of employment. Proceedings before the court of arbitration may be applied if there is an arbitration clause. As long as there exists an agreement as regards the arbitration clause, it cannot be demanded that the dispute be resolved by a common court. However, a state court may deem itself incompetent only as a result of an objection raised by the opposing party before it involves in a dispute as to the merits of the case.

\footnotetext{
38 Due to more complicated and formal procedures, more persons decides to hire attorneys.

39 Code of Civil Procedure of 13 April 1964, Journal of Laws No 16, item 93.
} 
Regulations pointing ADR schemes as an important way of out-of-court dispute resolutions can be found in the Act of 12 September 2002 on electronic instruments of payment ${ }^{40}$ as well as in the Regulation of 24 September 2002 on the determination of courts of arbitration competent to examine the cases in connection with issuing and using the electronic instruments of payment. This kind of proceedings is applicable upon the request of the "Holder," in case the parties have not made an arbitration clause. A "Holder" is a natural person, a legal person or other entity that, pursuant to the agreement on the electronic instrument of payment, makes on his/its behalf and to his/its benefit operations as referred to in the agreement. The defendant may object to the application of the discussed procedure to the case not later than as in response to the action. Regulation in the commonly binding legal provisions has been limited to the establishment of the possibility of applying the discussed proceedings and to the identification of competent courts.

There are three ADR schemes in Poland, that are members of FIN-NET: Bank's Consumer Arbitration, Insurance Ombudsman and Arbitration Court at the Financial Supervision Authority.

Bank's Consumer Arbitration ${ }^{41}$ (Banking ombudsman, Bankowy Arbitraż Konsumencki) is arbitration scheme that deal with complaints from bank's consumers. It is private and voluntary. The proceeding is not governed by the commonly binding legal regulations, but by virtue of the Resolution XII of the Polish Banks' General Assembly. A bank's arbitrator (ombudsman) is appointed by virtue of the Resolution of the Polish Banks' Association's Management Board.

The Insurance Ombudsman ${ }^{42}$ (Rzecznik Ubezpieczonych) is an institution established to represent the interest of policyholders, insurers, members of the Pension Funds and people, who are entitled to indemnification due to the insurance contracts, including victims of car accidents as well as members of pension funds. The Insurance Ombudsman represents consumers (individuals), as well as small, medium and even large enterprises.

Arbitration Court at the Financial Supervision Authority ${ }^{43}$ (Sąd Polubowny przy Komisji Nadzoru Finansowego) is a regular arbitration court competent to investigate the disputes concerning the proprietary and non-proprietary rights

\footnotetext{
40 Act of 12 September 2002 on electronic instruments of payment, Journal of Laws No 169, item 1385.

${ }^{41}$ See www.zbp.pl

${ }^{42}$ See www.rzu.gov.pl

${ }^{43}$ See www.knf.gov.pl
} 
that could constitute the subject of consent judgment between the participants of the financial market, in particular the disputes that result from the contractual relations between the entities that are subjected to the supervision of the Polish Financial Supervision Authority and the receivers of the services rendered by these entities.

\section{Conclusions}

Alternative Dispute Resolutions schemes play an important role as attractive way of redress. They increase customers protection and stabilize trust in financial sector. Moreover, ADR schemes bring advantages for both consumers and businesses, including financial institutions. That is why it is not discussed if they should exist in European Union, but what shape they should take.

Existing ADR schemes are still developing in the Member States and become more and more popular. Yet there are questions and problems, that should be solved by Member States, or even by European Union. If the single market is to function effectively, more have to be done to increase the effectiveness of the EU redress system. It is necessary to close the gaps in the current system, existing in individual States. Consumers should have clearly defined rights, which can be relied upon before national courts. They should be also reassured about access to redress in the case of cross-border financial transactions. There should by greater transparency to the way that redress is calculated, connected with raise awareness of ADR schemes and FIN-NET. For ADR bodies, four primary key conditions should be fulfilled: independence from the organizations (especially financial institutions), power (right) to investigate, free and easy accessibility for complainants (it includes fee, that would not restrain complaints) and finally fairness and public accountability.

Besides all advantages of ADR schemes for all parts of financial services, developments are still fairly modest and- as for now- do not involve any attempt to construct a supra-national dispute resolution infrastructure. Instead the emphasis is on co-operative linkages between national schemes so as to provide consumers of cross-border financial services with access to the alternative dispute settlement body of other EU states via the redress body in their own country of residence. The example for it is FIN-NET. With increasing number of cross-border transactions, conducting through the internet, it will be necessary to strengthen cooperation among ADR bodies in the Member States. It may be done by international web like FIN-NET, but it should be considered, if Paneuropean ADR body or 
supra-national dispute resolution infrastructure would not be more efficient, especially in Online Dispute Resolutions.

Finally, beside law regulations on ADR schemes, there should be room for self-regulation of market participants (soft law). Self regulation clearly has a role to play in ensuring effective and efficient regulation of complex, dynamic financial markets. It draws upon the knowledge and expertise of sophisticated market participants, that are parties of financial services. With the benefit of access to industry expertise, self regulation should often be better placed than state regulation to devise quick and effective responses to new regulatory challenges. Its solutions are ones that market participants should more readily accept since they have had a hand in developing them. Consumers should have right to chose among public court, ADR body that is supervised by state organization or private ADR body. Competition between those ADR schemes should bring increase of effectiveness of proceedings and quality of decisions. Consumer should also have right to decide, if the decision of ADR schemes should be binding for him. 